\title{
Enhanced Activity and Stability of Pt/C Fuel Cell Anodes by the Modification with Ruthenium-Oxide Nanosheets
}

\author{
Takahiro Saida, Wataru Sugimoto, ${ }^{1, *}$ and Yoshio Takasu ${ }^{1}$ \\ Department of Fine Materials Engineering, Faculty of Textile Science and Technology, Shinshu \\ University, 3-15-1 Tokida, Ueda 386-8567, JAPAN
}

\begin{abstract}
Ruthenium oxide nanosheet $\left(\mathrm{RuO}_{2} \mathrm{~ns}\right)$ crystallites with thickness less than $1 \mathrm{~nm}$ were prepared via chemical exfoliation of a layered potassium ruthenate and deposited onto carbon supported platinum $(\mathrm{Pt} / \mathrm{C})$ as a potential co-catalyst for fuel cell anode catalysts. The electrocatalytic activity towards carbon monoxide and methanol oxidation was studied at various temperatures with for different $\mathrm{RuO}_{2}$ ns loadings. An increase in electrocatalytic activity was evidenced at temperatures above $40^{\circ} \mathrm{C}$, while little enhancement in activity was observed at room temperature. The $\mathrm{RuO}_{2} \mathrm{~ns}$ modified $\mathrm{Pt} / \mathrm{C}$ catalyst with composition of $\mathrm{RuO}_{2}: \mathrm{Pt}=0.5: 1$ (molar ratio) exhibited the highest methanol oxidation activity. CO-stripping voltammetry revealed that $\mathrm{RuO}_{2}$ ns promotes oxidation of adsorbed $\mathrm{CO}$ on Pt. In addition to the enhanced initial activity, the $\mathrm{RuO}_{2}$ ns modified $\mathrm{Pt} / \mathrm{C}$ catalyst exhibited improved stability compared to pristine $\mathrm{Pt} / \mathrm{C}$ against consecutive potential cycling tests.
\end{abstract}

Keywords: Direct methanol fuel cell; CO oxidation; Platinum; Ruthenium oxide; Electrocatalyst; Nanosheet

\footnotetext{
${ }^{*}$ Corresponding author. Tel.: +81-268-21-5455; Fax: +81-268-21-5452

E-mail address: wsugi@shinshu-u.ac.jp (W. Sugimoto).

${ }^{1}$ ISE member
} 


\section{Introduction}

Development of anode catalysts with higher tolerance to catalyst poison and better stability are major issues that must be resolved for wide-spread commercialization of direct methanol fuel cells for portable electronics and polymer electrolyte fuel cells operating on reformed fuel for residential applications. The carbon supported platinum-ruthenium system is considered as one of the most promising anode catalysts for such fuel cells [1]. Metallic $\mathrm{Ru}$ in the alloy catalyst is known to promote the oxidation of the carbon monoxide. Carbon monoxide strongly adsorbs on the active $\mathrm{Pt}$ sites, inhibiting successive reaction of the fuel. The promotional effect of $\mathrm{Ru}$ has been mainly discussed based on the so-called "bi-functional mechanism" [2] and/or "ligand effect" [3]. The bifunctional mechanism is based on the assumption that $\mathrm{Ru}$ supplies an oxygen source $\left(\mathrm{Ru}-\mathrm{OH}_{\mathrm{ad}}\right)$ promoting the oxidation of $\mathrm{CO}$ on adjacent $\mathrm{Pt}$ sites. The ligand effect assumes that the energy level of the metal catalyst is modified so that the binding strength with the metal and adsorbed CO is weakened, resulting in a reduction in overpotential for $\mathrm{CO}$ oxidation. The possibility that some nanostructured ruthenium oxides (expressed as $\mathrm{RuO}_{x} \mathrm{H}_{y}$ or $\mathrm{RuO}_{2} \cdot x \mathrm{H}_{2} \mathrm{O}$ in the literature) may act as co-catalysts has attracted interest and debate [4-18]. Several studies have suggested that the binary PtRu alloy structure is not a prerequisite for obtaining the highest activity, and partially oxidized ruthenium species $\left(\mathrm{RuO}_{x}\right)$ that are present in the PtRu/C catalysts may contribute to the anodic activity [4-6]. Enhancement in methanol oxidation activity has been reported for $\mathrm{Pt}-\mathrm{RuO}_{2}$ composite catalysts although the activity of such material is in general lower than that of PtRu alloy [7-14]. On the contrary, other studies have reported that ruthenium oxide is inactive for CO oxidation [15-18]. One reason for the apparent inconsistency in the reported literature may be due to the various forms of ruthenium oxide with different oxidation states and hydrous states having different electrochemical characteristics.

In terms of catalyst stability, $\mathrm{Ru}$ has been reported to be vulnerable to dissolution under longterm fuel cell operation, especially by voltage fluctuation due to repeated start up and shut down [19-22]. It is well known that crystalline $\mathrm{RuO}_{2}$ has high electrochemical stability within the hydrogen and oxygen evolution region [23-30]. However, it has also been reported that hydrous ruthenium oxide containing $\mathrm{Ru}^{3+}$ is not stable in acidic electrolyte [30].

We have studied the electrochemical behavior of crystalline $\mathrm{RuO}_{2}$ nanosheet $\left(\mathrm{RuO}_{2} \mathrm{~ns}\right)$ electrodes derived by chemical exfoliation of layered $\mathrm{K}_{0.2} \mathrm{RuO}_{2.1}$. The negatively charged $\mathrm{RuO}_{2}$ nanosheets with sub-nanometer thickness are stabilized as a colloid by tetrabutylammonium counter ions [25]. Earlier, we communicated that the modification of $\mathrm{Pt} / \mathrm{C}$ with $\mathrm{RuO}_{2}$ nanosheets decreases the potential for $\mathrm{CO}$ and $\mathrm{CH}_{3} \mathrm{OH}$ electro-oxidation at $60^{\circ} \mathrm{C}$ [31]. In the case of alloy catalysts, it has been reported that the optimal alloy composition changes as a function of temperature; Ru-rich catalysts $(\mathrm{Pt}: \mathrm{Ru}=1: 1)$ are more active at $60^{\circ} \mathrm{C}$ while Pt-rich catalysts $(\mathrm{Pt}: \mathrm{Ru}=3: 1)$ are more active at $25^{\circ} \mathrm{C}$ [32-34]. Thus, it is essential that the activity at different temperatures with different co-catalyst loadings is studied. In this work, a systematic investigation of the $\mathrm{CO}$ and $\mathrm{CH}_{3} \mathrm{OH}$ oxidation activity on $\mathrm{RuO}_{2}$ ns modified $\mathrm{Pt} / \mathrm{C}\left(\mathrm{RuO}_{2} \mathrm{~ns}-\mathrm{Pt} / \mathrm{C}\right)$ was conducted with various $\mathrm{RuO}_{2}$ nanosheet content at temperatures ranging from 25 to $60^{\circ} \mathrm{C}$ in order to further understand the effect of the $\mathrm{RuO}_{2}$ nanosheet modification. In addition, the stability of $\mathrm{RuO}_{2} \mathrm{~ns}-$ $\mathrm{Pt} / \mathrm{C}$ was compared with pristine $\mathrm{Pt} / \mathrm{C}$. 


\section{Experimental}

An aqueous colloid containing exfoliated $\mathrm{RuO}_{2}$ nanosheet crystallites was prepared following a procedure reported earlier [25]. First, layered $\mathrm{K}_{0.2} \mathrm{RuO}_{2.1}$ was obtained by solid-state reaction. The interlayer $\mathrm{K}^{+}$was exchanged with $\mathrm{H}^{+}$by acid treatment to obtain layered $\mathrm{H}_{0.2} \mathrm{RuO}_{2.1}$ (residual potassium $\mathrm{K} / \mathrm{Ru}<0.05: 1$ [25]). Layered $\mathrm{H}_{0.2} \mathrm{RuO}_{2.1}$ was then reacted with $50 \%$ aqueous ethylamine to obtain an ethylammonium-ruthenate intercalation compound, $\left(\mathrm{C}_{2} \mathrm{H}_{5} \mathrm{NH}_{3}\right)_{0.2} \mathrm{RuO}_{2.1}$. The interlayer ethylammonium was subsequently ion-exchanged with tetrabutylammonium by reaction of the ethylammonium-ruthenate intercalation compound with $10 \%$ aqueous tetrabutylammonium hydroxide, yielding a tetrabutylammonium-ruthenate intercalation compound, $\left(\left(\mathrm{C}_{4} \mathrm{H}_{9}\right)_{4} \mathrm{~N}\right)_{0.2} \mathrm{RuO}_{2.1}$. The solid product was centrifugally collected $(15,000 \mathrm{rpm})$. The tetrabutylammonium-ruthenate intercalation compound in a powder form was dispersed in distilled water and subjected to ultrasonification for $30 \mathrm{~min}$ and centrifuged at 2,000 rpm. The colloidal supernatant, which contains the exfoliated $\mathrm{RuO}_{2}$ nanosheets $\left(\mathrm{RuO}_{2} \mathrm{~ns}\right)$, was used for further investigation.

Carbon supported Pt (30 mass\% $\%$ Pt) was prepared by an impregnation method reported previously $[35,36]$. Vulcan $\mathrm{XC}-72 \mathrm{R}$ was mixed with $\mathrm{Pt}\left(\mathrm{NO}_{2}\right)_{2}\left(\mathrm{NH}_{3}\right)_{2}$ dissolved in ethanol, and then allowed to dry at $60^{\circ} \mathrm{C}$ to a powder state. The dried precursor was reduced in a tube furnace under flowing $\mathrm{H}_{2}(10 \%)-\mathrm{N}_{2}(90 \%)$ gas for 2 hours at $200^{\circ} \mathrm{C}$. $\mathrm{Pt} / \mathrm{C}$ was suspended in distilled water and added into the $\mathrm{RuO}_{2}$ ns colloid and thoroughly mixed. The amount of $\mathrm{Pt} / \mathrm{C}$ added to the $\mathrm{RuO}_{2}$ ns colloid was controlled so that the molar ratio of the additive was $\mathrm{RuO}_{2}: \mathrm{Pt}=1: 1,0.5: 1$ and 0.2:1. Reaction of $\mathrm{Pt} / \mathrm{C}$ with the $\mathrm{RuO}_{2} \mathrm{~ns}$ could be realized by sedimentation. The final product, $\mathrm{RuO}_{2} \mathrm{~ns}$ modified $\mathrm{Pt} / \mathrm{C}$, was obtained by drying the mixture at $80^{\circ} \mathrm{C}$. The samples will be denoted as $\mathrm{RuO}_{2} \mathrm{~ns}(1.0)-\mathrm{Pt} / \mathrm{C}, \mathrm{RuO}_{2} \mathrm{~ns}(0.5)-\mathrm{Pt} / \mathrm{C}$, and $\mathrm{RuO}_{2} \mathrm{~ns}(0.2)-\mathrm{Pt} / \mathrm{C}$, according to the amount of $\mathrm{RuO}_{2}$ in the composite. For comparative reasons, $\mathrm{RuO}_{2} \mathrm{~ns}$ supported on carbon, $\mathrm{RuO}_{2} \mathrm{~ns} / \mathrm{C}(10$ mass $\%$ $\mathrm{RuO}_{2}$ ), and $\mathrm{PtRu} / \mathrm{C}\left(20\right.$ mass\% $\mathrm{Pt}$ and 10 mass\% $\mathrm{Ru}$; $\mathrm{Ru}$ source $\mathrm{Ru}\left(\mathrm{NO}_{3}\right)_{3}$ dissolved in ethanol) were also prepared. The prepared $\mathrm{PtRu} / \mathrm{C}$ catalyst shows activity comparable to values reported in literature $[18,32,37]$. The metal ratio in the samples was analyzed by energy-dispersive X-ray spectroscopy (EDX) (EMAX-7000; Noran Instruments Voyager). The structure of the catalysts was characterized by X-ray diffraction (XRD, Rigaku RINT-2550 with monochromated $\mathrm{CuK} \alpha$ radiation at $40 \mathrm{kV}$ and $50 \mathrm{~mA}$ ).

The working electrode was prepared by depositing $20 \mu \mathrm{L}$ of a $2 \mathrm{~g} \mathrm{~L}^{-1}$ electrocatalyst ink dispersed in distilled water on a mirror-polished glassy carbon rod (40 $\mu \mathrm{g}$-catalyst per $0.196 \mathrm{~cm}^{2}$ exposed surface) with a micropipette. For electrochemical studies, the overall amount of catalyst was kept constant, giving metal loadings for the non-modified electrodes as $12 \mu \mathrm{g}$-metal for Pt/C and PtRu/C. For the $\mathrm{RuO}_{2}$ nanosheet modified electrodes, the Pt loadings are 11.5, 10.9, and 10 $\mu \mathrm{g}-\mathrm{Pt} \mathrm{cm}{ }^{-2}$ for $\mathrm{RuO}_{2} \mathrm{~ns}: \mathrm{Pt}$ with $0.2,0.5$, and 1.0. $20 \mu \mathrm{L}$ of a $1 \mathrm{wt} \%$ Nafion ionomer (resulting in a calculated Nafion thickness of $\sim 4.5 \mu \mathrm{m}$ ) was dropped onto the electrode surface to immobilize the electrocatalysts. A beaker-type electrochemical cell equipped with the working electrode, a platinum mesh counter electrode and an $\mathrm{Ag} / \mathrm{AgCl} / \mathrm{KCl}$ (sat.) reference electrode, connected with a salt bridge, was used. A Luggin capillary faced the working electrode at a distance of $2 \mathrm{~mm}$. Electrochemical measurements were conducted at 25, 30, 40, 50 and $60^{\circ} \mathrm{C}$. All electrode 
potentials throughout the paper will be referred to the reversible hydrogen electrode (RHE) scale corrected for the temperature effect $(\operatorname{RHE}(t))$ according to the following equation:

$$
E \text { vs } \mathrm{RHE}(t)=E \text { vs } \mathrm{Ag} / \mathrm{AgCl}+(224-T) \times \frac{\partial T}{\partial E}-\frac{R T}{n F} \times \mathrm{pH} \times 2.303
$$

where $R$ is the gas constant $\left(8.314 \mathrm{~J} \mathrm{~K}^{-1} \mathrm{~mol}^{-1}\right), T$ is the temperature, $n$ is the number of electrons involved in the reaction (in this case, $n=1), F$ is the Faraday constant $\left(96,485 \mathrm{C} \mathrm{mol}^{-1}\right.$ ) and $\partial T / \partial E$ is $0.0010 \mathrm{~K} \mathrm{~V}^{-1}$.

Oxidation of pre-adsorbed carbon monoxide $\left(\mathrm{CO}_{\mathrm{ad}}\right)$ was measured by $\mathrm{CO}_{\mathrm{ad}}$ stripping voltammetry in $0.5 \mathrm{M} \mathrm{H}_{2} \mathrm{SO}_{4}$ at a scan rate of $10 \mathrm{mV} \mathrm{s}^{-1}$. Gaseous $\mathrm{CO}(10 \%)-\mathrm{N}_{2}(90 \%)$ was purged into the $0.5 \mathrm{M} \mathrm{H}_{2} \mathrm{SO}_{4}$ electrolyte for $90 \mathrm{~min}$ to allow complete adsorption of $\mathrm{CO}$ onto the catalyst surface while maintaining a constant voltage of $50 \mathrm{mV}$ vs. RHE $(t)$. Excess CO in the electrolyte was then purged out by bubbling $\mathrm{N}_{2}$ gas for $40 \mathrm{~min}$. The electrochemical surface area (ECSA) of the catalysts was calculated from the CO-stripping voltammograms. The amount of $\mathrm{CO}_{\mathrm{ad}}$ was measured by integration of the $\mathrm{CO}_{\mathrm{ad}}$ stripping peak, corrected for the electrical double-layer capacitance, assuming a monolayer of linearly adsorbed $\mathrm{CO}$ on metal surface and the Coulombic charge necessary for oxidation as $420 \mu \mathrm{C} \mathrm{cm}^{-2}$. Electro-oxidation of $\mathrm{CH}_{3} \mathrm{OH}$ was characterized by chronoamperometry at $500 \mathrm{mV}$ in $0.5 \mathrm{M} \mathrm{H}_{2} \mathrm{SO}_{4}$ containing $1 \mathrm{M} \mathrm{CH}_{3} \mathrm{OH}$ at various temperatures. The ECSA obtained from CO-stripping voltammetry was used to calculate the specific activity, i.e., the quasi-steady state current for methanol electro-oxidation obtained by chronoamperometry after $30 \mathrm{~min}$ of polarization normalized by the ECSA. The mass activity was obtained by normalizing to the amount of Pt coated onto the glassy carbon surface. Catalyst stability was characterized by measuring the methanol oxidation activity after the catalysts were subjected to potential cycling. After the initial methanol oxidation activity was measured, the electrolyte was changed to a fresh $0.5 \mathrm{M} \mathrm{H}_{2} \mathrm{SO}_{4}$ electrolyte free of methanol. The potential was then cycled between 0.05 and $1.2 \mathrm{~V}$ at $50 \mathrm{mV} \mathrm{s}^{-1}$ for 1,000 cycles at $60^{\circ} \mathrm{C}$. Methanol was then added into the electrolyte and the methanol oxidation activity was again measured by chronoamperometry.

\section{Results and Discussion}

\subsection{Structural characterization}

Figure 1(a) shows the XRD pattern of a film obtained by casting the $\mathrm{RuO}_{2}$ ns colloid. A series of $(00 l)$ diffraction peaks typical of a well-ordered layered structure with an interlayer spacing of $\sim 1.7 \mathrm{~nm}$ is observed. Thus, by casting the $\mathrm{RuO}_{2} \mathrm{~ns}$ colloid, re-stacking and re-organization of the exfoliated $\mathrm{RuO}_{2}$ ns occurs resulting in a tetrabutylammonium intercalation compound. The lack of such two-dimensional ordering for $\mathrm{RuO}_{2} \mathrm{~ns}(0.5)-\mathrm{Pt} / \mathrm{C}$ (Fig. 1(b)) is evidence that $\mathrm{RuO}_{2} \mathrm{~ns}$ is deposited onto the carbon surface with negligible re-stacking. Weak diffraction peaks at $2 \theta=10$ and $35^{\circ}$ are observed, which is attributed to partial ordering of the $\mathrm{RuO}_{2} \mathrm{~ns}$. The $\mathrm{XRD}$ peaks attributed to metallic $\mathrm{Pt}$ in $\mathrm{RuO}_{2} \mathrm{~ns}(0.5)-\mathrm{Pt} / \mathrm{C}$ are identical in peak position and width with $\mathrm{Pt} / \mathrm{C}$. Thus, the $\mathrm{Pt}$ particle size is not affected by the $\mathrm{RuO}_{2} \mathrm{~ns}$ modification and there is no atomic alloying of $\mathrm{Ru}$ into the $\mathrm{Pt}$ structure. This is anticipated since the $\mathrm{RuO}_{2} \mathrm{~ns}-\mathrm{Pt} / \mathrm{C}$ composite is not exposed to any heat treatment other than the drying process. The observed $\mathrm{Ru}: \mathrm{Pt}$ ratio of the prepared catalyst as determined by energy dispersive X-ray measurements was $\mathrm{Ru}: \mathrm{Pt}=0.92: 1$, 
0.52:1, 0.15:1 for $\mathrm{RuO}_{2} \mathrm{~ns}(1.0)-\mathrm{Pt} / \mathrm{C}, \mathrm{RuO}_{2} \mathrm{~ns}(0.5)-\mathrm{Pt} / \mathrm{C}$, and $\mathrm{RuO}_{2} \mathrm{~ns}(0.2)-\mathrm{Pt} / \mathrm{C}$, in agreement with the nominal content.

\subsection{Electrochemical properties of $\mathrm{RuO}_{2} \mathrm{~ns} / \mathrm{C}$}

The electrochemical properties of $\mathrm{RuO}_{2} \mathrm{~ns} / \mathrm{C}(10$ mass $\%)$ in the absence of Pt nanoparticles were first evaluated to understand the electrocatalytic activity of $\mathrm{RuO}_{2} \mathrm{~ns}$ alone. The cyclic voltammograms of $\mathrm{RuO}_{2} \mathrm{~ns} / \mathrm{C}$ in $0.5 \mathrm{M} \mathrm{H}_{2} \mathrm{SO}_{4}$ at various temperatures are shown Fig. 2 . These voltammograms represent the background for the $\mathrm{RuO}_{2} \mathrm{~ns}-\mathrm{Pt} / \mathrm{C}$ composite. Three characteristic redox pairs are observed at $\sim 0.1,0.65$ and $0.8 \mathrm{~V}$ (hereafter denoted A1/C1, A2/C2, A3/C3). $\mathrm{A} 2 / \mathrm{C} 2$ and $\mathrm{A} 3 / \mathrm{C} 3$ are attributed to electrosorption of anionic and cationic species, respectively $[27,28] . \mathrm{A} 1 / \mathrm{Cl}$ is uncommon for polycrystalline $\mathrm{RuO}_{2}$ systems but bears similarity to peaks observed in high quality $\mathrm{RuO}_{2}$ (100) single crystal surfaces [38]. The A1/C1 pair is tentatively ascribed as adsorption/desorption of hydronium ions on the surface of the $\mathrm{RuO}_{2} \mathrm{~ns}$, similar to that observed on $\mathrm{RuO}_{2}$ (100) [38]. The specific capacitance of $\mathrm{RuO}_{2} \mathrm{~ns} / \mathrm{C}$, calculated by averaging the charge of the anodic and cathodic portion of the voltammograms, at $60^{\circ} \mathrm{C}$ was $\sim 73 \mathrm{~F}$ (g-catalyst) ${ }^{1}$ which translates to $\sim 732 \mathrm{~F}\left(\mathrm{~g}-\mathrm{RuO}_{2}\right)^{-1}$ at $10 \mathrm{mV} \mathrm{s}^{-1}$, comparable to the value of unsupported $\mathrm{RuO}_{2} \mathrm{~ns}$.

Figure 3 shows the $\mathrm{CO}_{a d}$ stripping voltammograms for $\mathrm{RuO}_{2} \mathrm{~ns} / \mathrm{C}$ at various temperatures. It is clear that $\mathrm{RuO}_{2} \mathrm{~ns}$ behaves as a poor electrocatalyst for $\mathrm{CO}$ oxidation. The poor $\mathrm{CO}$ oxidation behavior of $\mathrm{RuO}_{2} \mathrm{~ns}$ can be attributed to the lack of $\mathrm{CO}$ adsorption sites on the $\mathrm{RuO}_{2} \mathrm{~ns}$ surface. Note that the $\mathrm{A} 1 / \mathrm{C} 1$ peak is still evident after the $\mathrm{CO}$ adsorption procedure. If the $\mathrm{A} 1 / \mathrm{C} 1$ peak was due to hydrogen desorption/adsorption similar to many metal surfaces, this peak is anticipated to disappear by the replacement of hydrogen with $\mathrm{CO}$. As this is not the case, the $\mathrm{A} 1 / \mathrm{C} 1$ peak is probably not due to hydrogen desorption/adsorption.

Voltammograms in $0.5 \mathrm{M} \mathrm{H}_{2} \mathrm{SO}_{4}+1 \mathrm{M} \mathrm{CH}_{3} \mathrm{OH}$ of $\mathrm{RuO}_{2} \mathrm{~ns} / \mathrm{C}$ at various temperatures are shown in Fig. 4. There is essentially no difference between the voltammograms with and without $\mathrm{CH}_{3} \mathrm{OH}$ in the electrolyte below $\sim 1.0 \mathrm{~V}$. Evidently, $\mathrm{CH}_{3} \mathrm{OH}$ adsorption does not occur on the surface of $\mathrm{RuO}_{2}$ nanosheets in the region of practical meaning to anode catalysts for fuel cells. The above results show that $\mathrm{RuO}_{2} \mathrm{~ns}$ single-handedly is a poor electrocatalyst for $\mathrm{CO}$ and $\mathrm{CH}_{3} \mathrm{OH}$ oxidation.

\section{$3.3 \mathrm{CO}$ tolerance of $\mathrm{RuO}_{2} \mathrm{~ns}-\mathrm{Pt} / \mathrm{C}$ with different $\mathrm{RuO}{ }_{2} \mathrm{~ns}$ loading}

Cyclic voltammograms of $\mathrm{RuO}_{2} \mathrm{~ns}-\mathrm{Pt} / \mathrm{C}$ with various $\mathrm{RuO}_{2}$ ns content in $0.5 \mathrm{M} \mathrm{H}_{2} \mathrm{SO}_{4}\left(60^{\circ} \mathrm{C}\right)$ are shown Fig. 5. The $\mathrm{CVs}$ of $\mathrm{RuO}_{2} \mathrm{~ns}-\mathrm{Pt} / \mathrm{C}$ are characterized by features of both $\mathrm{RuO}_{2} \mathrm{~ns} / \mathrm{C}$ and $\mathrm{Pt} / \mathrm{C}$. The $\mathrm{A} 1 / \mathrm{C} 1, \mathrm{~A} 2 / \mathrm{C} 2$ and $\mathrm{A} 3 / \mathrm{C} 3$ redox peaks distinctive of $\mathrm{RuO}_{2}$ ns can be clearly observed for all catalysts with different $\mathrm{RuO}_{2}$ ns loading. The charge related with these redox peaks increases with increasing $\mathrm{RuO}_{2} \mathrm{~ns}$ content. The gravimetric capacitance also increases linearly with the $\mathrm{RuO}_{2} \mathrm{~ns}$ content (Table I). The $\mathrm{CO}_{\mathrm{ad}}$ stripping voltammograms of $\mathrm{RuO}_{2} \mathrm{~ns}-\mathrm{Pt} / \mathrm{C}$ with different $\mathrm{RuO}_{2} \mathrm{~ns}$ loading at $60^{\circ} \mathrm{C}$ are shown Fig. 6. The onset and peak potential of $\mathrm{CO}_{\mathrm{ad}}$ oxidation for $\mathrm{RuO}_{2} \mathrm{~ns}-$ $\mathrm{Pt} / \mathrm{C}$ shows a negative shift compared to pure $\mathrm{Pt} / \mathrm{C}$. Although the $\mathrm{CO}$ tolerance of $\mathrm{RuO}_{2} \mathrm{~ns}-\mathrm{Pt} / \mathrm{C}$ is not as good compared to $\mathrm{PtRu} / \mathrm{C}$, a gain of $\sim 180 \mathrm{mV}$ in the onset for $\mathrm{CO}_{\mathrm{ad}}$ oxidation is observed by the modification of $\mathrm{Pt} / \mathrm{C}$ with $\mathrm{RuO}_{2}$ ns. Since $\mathrm{RuO}_{2}$ ns itself is a poor $\mathrm{CO}$ oxidation catalyst, the 
enhanced $\mathrm{CO}_{\mathrm{ad}}$ oxidation activity of $\mathrm{RuO}_{2} \mathrm{~ns}-\mathrm{Pt} / \mathrm{C}$ must be due to the ability of the $\mathrm{RuO}_{2} \mathrm{~ns}$ surface to supply an oxygen source $(-\mathrm{OH})$ for the oxidation of $\mathrm{CO}_{\mathrm{ad}}$ on the Pt surface. For $\mathrm{RuO}_{2} \mathrm{~ns}(0.2)$ $\mathrm{Pt} / \mathrm{C}$, the promotional effect is seen only as a small shoulder peak on the negative potential side, and the potential for the main peak is more or less the same as $\mathrm{Pt} / \mathrm{C}$. For $\mathrm{RuO}_{2} \mathrm{~ns}(0.5)-\mathrm{Pt} / \mathrm{C}$ and $\mathrm{RuO}_{2} \mathrm{~ns}(1.0)-\mathrm{Pt} / \mathrm{C}$, the shift in the onset potential of $\mathrm{CO}_{\mathrm{ad}}$ oxidation is more clear. It should be emphasized that the main $\mathrm{CO}_{\mathrm{ad}}$ oxidation peak is also shifted with regards to pure $\mathrm{Pt}(E=0.7 \mathrm{~V})$ for the catalysts with higher $\mathrm{RuO}_{2}$ ns content, i.e. $\mathrm{RuO}_{2} \mathrm{~ns}(0.5)-\mathrm{Pt} / \mathrm{C}$ and $\mathrm{RuO}_{2} \mathrm{~ns}(1.0)-\mathrm{Pt} / \mathrm{C}$. The peak broadening and the shift in onset and peak potential observed for the higher loadings can be explained by the $\mathrm{OH}$ nucleation and diffusion on the $\mathrm{RuO}_{2} \mathrm{~ns}$ surface to nearby Pt sites. The reactions sites for $\mathrm{CO}_{\mathrm{ad}}$ oxidation should be confined to sites where the $\mathrm{RuO}_{2}$ ns surface is in contact with the Pt surface. The broad and multiplex $\mathrm{CO}_{\mathrm{ad}}$ oxidation peak can be interpreted as a result of the heterogeneous interface between $\mathrm{RuO}_{2}$ nanosheets and Pt. Surface diffusion of $\mathrm{OH}$ groups on the $\mathrm{RuO}_{2}$ nanosheet surface should be the main cause for the sluggish kinetics. The limited co-catalytic effect of $\mathrm{RuO}_{2} \mathrm{~ns}$ at low loading can be rationalized as insufficient contact between $\mathrm{Pt}$ nanoparticles and $\mathrm{RuO}_{2}$ ns. The sluggish $\mathrm{CO}$ oxidation kinetics of the $\mathrm{RuO}_{2} \mathrm{~ns}-\mathrm{Pt} / \mathrm{C}$ is similar to the behavior observed for $\mathrm{Pt} / \mathrm{RuO}_{2}$ catalysts. Surface diffusion of $\mathrm{CO}_{\mathrm{ad}}$ has been shown to play a significant role in the $\mathrm{CO}$ oxidation reaction for $\mathrm{Pt}-\mathrm{Ru}$ as well as $\mathrm{Pt} / \mathrm{RuO}_{2}$ catalaysts [39]. As the $\mathrm{Pt}$ particle size for the $\mathrm{RuO}_{2} \mathrm{~ns}-\mathrm{Pt} / \mathrm{C}$ catalysts are all the same in this study, the $\mathrm{CO}$ oxidation kinetics most likely is governed by the $\mathrm{OH}$ nucleation and diffusion rate on the $\mathrm{RuO}_{2} \mathrm{~ns}$ surface.

Quantitative evaluation of the Pt surface area from the hydrogen adsorption/desorption peaks was not possible due to the overlapping of the $\mathrm{A} 1 / \mathrm{Cl}$ redox peaks from $\mathrm{RuO}_{2} \mathrm{~ns}$. The effective $\mathrm{Pt}$ surface area was thus estimated from the $\mathrm{CO}_{\mathrm{ad}}$ oxidation charge. The electrochemically active $\mathrm{Pt}$ surface area $\left(S_{\mathrm{ECA}}\right)$ obtained from CO stripping is summarized in Table I. Note that the $S_{\mathrm{ECA}}$ is a measure of only the electrochemically active Pt surface sites as $\mathrm{CO}$ does not adsorb on $\mathrm{RuO}_{2} \mathrm{~ns}$. The modification with $\mathrm{RuO}_{2}$ ns induces an increase in $S_{\mathrm{ECA}}$. $\mathrm{RuO}_{2} \mathrm{~ns}$ has a hydrophilic surface which may result in an increase in the interphase between the electrolyte and Pt nanoparticles.

Figure 7 shows the effect of temperature on the $\mathrm{CO}_{\mathrm{ad}}$ stripping voltammograms for $\mathrm{RuO}_{2} \mathrm{~ns}(0.5)-\mathrm{Pt} / \mathrm{C}, \mathrm{Pt} / \mathrm{C}$ and $\mathrm{PtRu} / \mathrm{C}$. The shape of the $\mathrm{CO}_{\mathrm{ad}}$ oxidation peak for $\mathrm{RuO}_{2} \mathrm{~ns}(0.5)-\mathrm{Pt} / \mathrm{C}$ is strongly affected by the temperature. At $25^{\circ} \mathrm{C}$, the $\mathrm{CO}_{\mathrm{ad}}$ stripping voltammogram of $\mathrm{RuO}_{2} \mathrm{~ns}(0.5)-\mathrm{Pt} / \mathrm{C}$ is similar to that of $\mathrm{Pt} / \mathrm{C}$, indicating that $\mathrm{RuO}_{2} \mathrm{~ns}$ does not promote $\mathrm{CO}_{\mathrm{ad}}$ oxidation. The co-catalytic effect of $\mathrm{RuO}_{2} \mathrm{~ns}$ becomes obvious as the reaction temperature is increased, as evidenced by the gradual broadening and splitting of the $\mathrm{CO}_{\mathrm{ad}}$ oxidation peak with increasing temperature. Although $\mathrm{RuO}_{2} \mathrm{~ns}$ acts as a promoting additive, it is not as effective as $\mathrm{Ru}$ in the PtRu alloy. Obviously, the Pt nanoparticles and $\mathrm{RuO}_{2} \mathrm{~ns}$ have limited contact compared to an intimately mixed PtRu alloy and an electronic effect is rather unlikely. However, the $\mathrm{CO}$ tolerance of $\mathrm{RuO}_{2} \mathrm{~ns}(1.0)-\mathrm{Pt} / \mathrm{C}$ is comparable to $\mathrm{PtRu} / \mathrm{C}$ at elevated temperatures, where $\mathrm{PtRu} / \mathrm{C}$ stability may become a major issue. The instability of $\mathrm{Ru}$ under the fuel cell operation conditions has been reported [20-22]. The amount of $\mathrm{Ru}$ loss due to dissolution should increase with increasing cell temperature.

\section{4 $\mathrm{CH}_{3} \mathrm{OH}$ oxidation activity of $\mathrm{RuO} \mathrm{O}_{2} \mathrm{~ns}-\mathrm{Pt} / \mathrm{C}$}


Chronoamperograms of $\mathrm{RuO}_{2} \mathrm{~ns}-\mathrm{Pt} / \mathrm{C}, \mathrm{Pt} / \mathrm{C}$ and $\mathrm{PtRu} / \mathrm{C}$ catalysts in $0.5 \mathrm{M} \mathrm{H}_{2} \mathrm{SO}_{4}+1 \mathrm{M}$ $\mathrm{CH}_{3} \mathrm{OH}\left(60^{\circ} \mathrm{C}\right)$ are shown in Fig. 8. The mass and specific activities of methanol oxidation calculated from the quasi-steady state current after $30 \mathrm{~min}$. are summarized in Table II. The specific activity (the current density normalized by the $S_{\mathrm{ECA}}$ of $\mathrm{Pt}$ obtained from CO-stripping voltammetry) for $\mathrm{RuO}_{2}(0.5)-\mathrm{Pt} / \mathrm{C}$ was almost as high as $\mathrm{PtRu} / \mathrm{C}$, and roughly 8 times higher than that of $\mathrm{Pt} / \mathrm{C}$. The mass activity for $\mathrm{CH}_{3} \mathrm{OH}$ oxidation for $\mathrm{RuO}_{2}(0.5)-\mathrm{Pt} / \mathrm{C}$ and $\mathrm{RuO}_{2}(1.0)-\mathrm{Pt} / \mathrm{C}$ showed an enhancement of approximately 10 times compared to $\mathrm{Pt} / \mathrm{C}$. It is obvious that $\mathrm{RuO}_{2} \mathrm{~ns}$ acts as a co-catalyst for $\mathrm{CH}_{3} \mathrm{OH}$ oxidation due to the enhanced $\mathrm{CO}_{\text {ad }}$ oxidation activity.

The temperature dependence of the $\mathrm{CH}_{3} \mathrm{OH}$ oxidation activity was studied for the $\mathrm{RuO}_{2} \mathrm{~ns}(0.5)$ $\mathrm{Pt} / \mathrm{C}$ catalyst. The voltammograms measured at various temperatures for $\mathrm{RuO}_{2} \mathrm{~ns}(0.5)-\mathrm{Pt} / \mathrm{C}$ are compared with $\mathrm{Pt} / \mathrm{C}$ and $\mathrm{PtRu} / \mathrm{C}$ in Fig. 9. The temperature dependence of $\mathrm{CH}_{3} \mathrm{OH}$ oxidation follows a similar tendency to the $\mathrm{CO}_{\mathrm{ad}}$ oxidation behavior, which is not surprising since $\mathrm{CO}$ poisoning occurs only on $\mathrm{Pt}$ sites as mentioned earlier. At elevated temperatures, the $\mathrm{CH}_{3} \mathrm{OH}$ oxidation activity of $\mathrm{RuO}_{2} \mathrm{~ns}(0.5)-\mathrm{Pt} / \mathrm{C}$ catalyst is higher compared to $\mathrm{Pt} / \mathrm{C}$, but is slightly lower than that of $\mathrm{PtRu} / \mathrm{C}$. At ambient temperature, $\mathrm{CH}_{3} \mathrm{OH}$ oxidation on $\mathrm{RuO}_{2} \mathrm{~ns}(0.5)-\mathrm{Pt} / \mathrm{C}$ is similar to that of $\mathrm{Pt} / \mathrm{C}$, since diffusion of $\mathrm{OH}_{\mathrm{ad}}$ on $\mathrm{RuO}_{2} \mathrm{~ns}$ is not sufficient for the $\mathrm{RuO}_{2}$ ns to participate in the oxidation of the intermediate products. The temperature dependence of the mass activity obtained from chronoamperometry in $0.5 \mathrm{M} \mathrm{H}_{2} \mathrm{SO}_{4}+1 \mathrm{M} \mathrm{CH}_{3} \mathrm{OH}$ for $\mathrm{RuO}_{2} \mathrm{~ns}(0.5)-\mathrm{Pt} / \mathrm{C}, \mathrm{Pt} / \mathrm{C}$ and $\mathrm{PtRu} / \mathrm{C}$ are shown in Fig. 10. The slope in the $\log j-T^{1}$ curve for $\mathrm{RuO}_{2} \mathrm{~ns}-\mathrm{Pt} / \mathrm{C}$ was larger compared to $\mathrm{Pt} / \mathrm{C}$ and $\mathrm{PtRu} / \mathrm{C}$, showing the strong temperature dependence of the co-catalytic effect of $\mathrm{RuO}_{2}$ ns. The apparent activation energy $E_{\text {a }}$ estimated from the slope in the $\log j-T^{-1}$ curve for $\mathrm{RuO}_{2} \mathrm{~ns}(0.5)-\mathrm{Pt} / \mathrm{C}$ was $\sim 102 \mathrm{~kJ} \mathrm{~mol}^{-1}$, while for $\mathrm{Pt} / \mathrm{C}$ and $\mathrm{PtRu} / \mathrm{C} E_{\mathrm{a}}$ was $\sim 53$ and $\sim 33 \mathrm{~kJ}$ $\mathrm{mol}^{-1}$, respectively.

\subsection{Stability of $\mathrm{RuO}_{2} \mathrm{~ns}(0.5)-\mathrm{Pt} / \mathrm{C}$ and $\mathrm{Pt} / \mathrm{C}$}

It has been reported that metallic $\mathrm{Ru}$ in the PtRu alloy catalyst dissolves as $\mathrm{Ru}^{n+}$ and deposits at the cathode under fuel cell operating conditions, leading to catalyst degradation [20-22]. Thus, the stability of $\mathrm{RuO}_{2} \mathrm{~ns}(0.5)-\mathrm{Pt} / \mathrm{C}$ was considered by an accelerated stability test (potential cycling between $0.05-1.2 \mathrm{~V}$ vs. RHE in $0.5 \mathrm{M} \mathrm{H}_{2} \mathrm{SO}_{4}\left(60^{\circ} \mathrm{C}\right)$ at $50 \mathrm{mV} \mathrm{s}^{-1}$ for 1,000 cycles). Figure 11 compares cyclic voltammograms in $0.5 \mathrm{M} \mathrm{H}_{2} \mathrm{SO}_{4}\left(60^{\circ} \mathrm{C}\right)$ for $\mathrm{RuO}_{2} \mathrm{~ns}(0.5)-\mathrm{Pt} / \mathrm{C}, \mathrm{Pt} / \mathrm{C}$, and $\mathrm{PtRu} / \mathrm{C}$ before and after the stability test. The results show that $\mathrm{RuO}_{2} \mathrm{~ns}$ is stable under conditions that $\mathrm{PtRu}$ would be drastically de-activated due to irreversible oxidation of $\mathrm{Ru}$. The $S_{\mathrm{ECA}}$ obtained from the hydrogen adsorption current for $\mathrm{Pt} / \mathrm{C}$ decreased drastically from $S_{\mathrm{ECA}}=57$ to $14 \mathrm{~m}^{2}$ (g-Pt) after the stability test. In the case of $\mathrm{RuO}_{2} \mathrm{~ns}(0.5)-\mathrm{Pt} / \mathrm{C}$, the $S_{\mathrm{ECA}}$ decreased only $55 \%$ in comparison with initial state, showing that the presence of $\mathrm{RuO}_{2} \mathrm{~ns}$ increases the stability of $\mathrm{Pt}$ nanoparticles. After the accelerated potential cycling test, the methanol oxidation activity of Pt/C retained only $\sim 14 \%$ of its initial activity, decreasing from 7 to $1 \mathrm{~A}(\mathrm{~g}-\mathrm{Pt})^{-1}$. Under the same stability test conditions, the methanol oxidation activity of $\mathrm{RuO}_{2} \mathrm{~ns}(0.5)-\mathrm{Pt} / \mathrm{C}$ was $20 \mathrm{~A}(\mathrm{~g}-\mathrm{Pt})^{-1}$. Thus $\sim 70 \%$ of the initial mass activity was maintained. The accelerated test conducted in this study is considerably intense bearing in mind that the anode potential of a fuel cell will not exceed $0.5 \mathrm{~V}$ in general. However, the results show that both activity and stability of $\mathrm{Pt} / \mathrm{C}$ were dramatically increased by modification with $\mathrm{RuO}_{2} \mathrm{~ns}$ under the present experimental conditions. The role of $\mathrm{RuO}_{2} \mathrm{~ns}$ towards the enhanced stability must be studied in more detail in order to reach 
a sound conclusion. A tentative explanation is given on the basis of the strong acidic nature of $\mathrm{RuO}_{2} \mathrm{~ns}$. $\mathrm{RuO}_{2} \mathrm{~ns}$ is intrinsically negatively charged $\left(\left[\mathrm{RuO}_{2.1}\right]^{0.2-}\right)$ and behaves as a solid acid, as indicated by the intercalation behavior of layered $\mathrm{H}_{0.2} \mathrm{RuO}_{2.1}$. Thus $\mathrm{RuO}_{2}$ ns should attract dissolved cationic $\mathrm{Pt}^{n+}$, thereby acting as a protective layer inhibiting the diffusion of $\mathrm{Pt}^{n+}$ into the electrolyte.

\section{Conclusions}

We have shown that high methanol oxidation activity is achieved by modifying conventional $\mathrm{Pt} / \mathrm{C}$ with crystalline $\mathrm{RuO}_{2}$ nanosheets $\left(\mathrm{RuO}_{2} \mathrm{~ns}\right)$. The highest activity was obtained for $\mathrm{RuO}_{2} \mathrm{~ns}-\mathrm{Pt} / \mathrm{C}$ with $\mathrm{RuO}_{2}: \mathrm{Pt}=0.5: 1$ (molar ratio) with a 10 fold increase in activity for methanol oxidation at 500 $\mathrm{mV}$ vs. $\mathrm{RHE}\left(60^{\circ} \mathrm{C}\right)$. The increased activity is attributed to the co-catalytic effect of $\mathrm{RuO}_{2} \mathrm{~ns}$ towards $\mathrm{CO}_{\mathrm{ad}}$ oxidation. The promotional effect is evident at temperatures above $40^{\circ} \mathrm{C}$, exhibiting a merit of $\sim 180 \mathrm{mV}$ for $\mathrm{CO}_{\mathrm{ad}}$ oxidation. At room temperature, $\mathrm{RuO}_{2} \mathrm{~ns}$ does not promote $\mathrm{CO}_{\mathrm{ad}}$ oxidation, most likely due to the poor kinetics of $\mathrm{OH}$ surface diffusion on $\mathrm{RuO}_{2} \mathrm{~ns}$. Accelerated potential cycling tests indicated that the stability of $\mathrm{RuO}_{2} \mathrm{~ns}-\mathrm{Pt} / \mathrm{C}$ is drastically enhanced compared to $\mathrm{Pt} / \mathrm{C}$, which has been tentatively attributed to the solid acid characteristic of $\mathrm{RuO}_{2} \mathrm{~ns}$, restraining the diffusion of $\mathrm{Pt}^{n+}$ into the electrolyte. $\mathrm{RuO}_{2} \mathrm{~ns}$ is an efficient co-catalyst exhibiting enhanced $\mathrm{CO}$ tolerance and improved catalyst stability.

\section{Acknowledgments}

The authors are grateful to Ishifuku Metal Industry Co., for kindly supplying $\operatorname{Pt}\left(\mathrm{NH}_{3}\right)_{2}\left(\mathrm{NO}_{2}\right)_{2}$. This work was supported in part by a Grant-in-Aid for Scientific Research No.18685026 and a Global COE Program by the Ministry of Education, Culture, Sports, Science, and Technology. 


\section{References}

[1] E. Antolini, Mater. Chem. Phys., 78 (2003) 563-578.

[2] M. Watanabe, M. Motoo, J. Electroanal. Chem. 60 (1975) 267.

[3] T. Frelink, W. Visscher, J.A.R. van Veen, Surf. Sci. 335 (1995) 353.

[4] D. R. Rolison, P. L. Hangans, K. E. Swider-Lyons, J. W. Long, Langmuir 15 (1999) 774.

[5] J. W. Long, R. M. Stroud, K. E. Swider-Lyons, and D. R. Rolison, J. Phys. Chem. B 104 (2000) 9772.

[6] B. J. Goodenough, A. Hamnett, B. J. Kennedy, R. Manoharan, S. A. Weeks, J. Electroanal. Chem. 240 (1988) 133.

[7] K. Lasch, G. Hayn, L. Jörissen, J. Garche, O. Besenhardt, J. Power Sources 105 (2002) 305.

[8] K. Lasch, L. Jörissen, K. A. Friedrich, J. Garche, J. Solid State Electrochem. 7 (2003) 619.

[9] Z. Chen, X. Qiu, B. Lu, S. Zhang, W. Zhu, L. Chen, Electrochem. Commun. 7 (2005) 593.

[10] H. M. Villullas, F. I. Mattos-Costa, L. O. S. Bulhões, J. Phys. Chem. B 108 (2004) 12898.

[11] H. B. Suffredini, V. Tricoli, L. A. Avsca, N. Vatistas, Electrochem. Commun. 6 (2004) 1025.

[12] L. Cao, F. Scheiba, C. Roth, F. Schweiger, C. Cremers, U. Stimming, H. Fuess, L. Chen, W. Zhu, X. Qiu, Angew. Chem. Int. Ed. 45 (2006) 5315.

[13] F. Scheiba, M. Scholz, L. Cao, R. Schafranek, C. Roth, C. Cremers, X. Qiu, U. Stimming, H. Fuess, Fuel Cells 6 (2006) 439.

[14] Z.-G. Shao, F. Zhu, W.-F. Lin, P. A. Christensen, H. Zhang, J. Power Sources 161 (2006) 813.

[15] A. H. C. Sirk, J. M. Hill, S. K. Y. Kung, V. I. Birss, J. Phys. Chem. B 108 (2004) 689.

[16] H. Hoster, T. Iwashita, H. Baumgärtner, W. Vilestich, J. Electrochem. Soc. 148 (2001) A496.

[17] W. E. O’Grady, P. L. Hagans, K. I. Pandya, D. L. Maricle, Langmuir 17 (2001) 3047.

[18] G. Wu, L. Li, B. Xu, Electrochim. Acta 50 (2004) 1.

[19] J. G. Liu, Z. H. Zhou, X. S. Zhao, Q. Xin, G. Q. Sun, B. L. Yi, Phys. Chem. Chem. Phys. 6 (2004) 134. 
[20] P. Piela, C. Eickes, E. Brosha, F. Garzon, P. Zelenay, J. Electrochem. Soc. 151 (2004) A2053.

[21] A. Taniguchi, T. Akita, K. Yasuda, Y. Miyazaki, J. Power Sources 130 (2004) 42.

[22] Y. Chung, C. Park, G.-Su Park, W. S. Jeon, J.-R. Kim, Y. Lee, H. Chang, D. Seung, J. Phys. Chem. C 112 (2008) 313.

[23] J. P. Zheng, T. R. Jow, J. Electrochem. Soc. 142 (1995) L6.

[24] J. P. Zheng, P. J. Cygan, T. R. Jow, J. Electrochem. Soc. 142 (1995) 2699.

[25] W. Sugimoto, H. Iwata, Y. Yasunaga, Y. Murakami, Y. Takasu, Angew. Chem. Int. Ed. 42 (2003) 4092.

[26] W. Sugimoto, T. Kizaki, K. Yokoshima, Y. Murakami, Y. Takasu, Electrochim. Acta 49 (2004) 313 .

[27] W. Sugimoto, H. Iwata, Y. Yasunaga, Y. Murakami, Y. Takasu, J. Electrochem. Soc. 151 (2004) A1181.

[28] W. Sugimoto, T. Ohta, K. Yokoshima, Y. Takasu, Electrochemistry 75 (2007) 645.

[29] W. Sugimoto, H. Iwata, K. Yokoshima, Y. Murakami, Y. Takasu, J. Phys. Chem. B 109 (2005) 7330.

[30] K.-H. Chang, C.C. Hu, J. Electrochem. Soc. 151 (2004) A958.

[31] W. Sugimoto, T.Saida, Y. Takasu, Electrochem. Commun. 8 (2006) 411.

[32] A. J. Dickinson, L. P. L. Carrette, J. A. Collins, K. A. Friedrich, U. Stimming, J. Appl. Electrochem. 34 (2004) 975.

[33] H. A. Gasteiger, N. Markovic, P. N. Ross Jr., E. J. Cairns, J. Electrochem. Soc. 141 (1994) 1795.

[34] A. S. Aricò, V. Baglio, A. D. Blasi, E. Modica, P. L. Antonucci, V. Antonucci, J. Electroanal. Chem. 557 (2003) 167.

[35] Y. Takasu, T. Fujiwara, Y. Murakami, K. Sasaki, M. Oguri, T. Asaki, W. Sugimoto, J. Electrochem. Soc. 147 (2000) 4421.

[36] Y. Takasu, H. Itaya, T. Kawaguchi, W. Sugimoto, Y. Murakami, Stud. Surf. Sci. Catal. 145 (2003) 279.

[37] T.J. Schmidt, H.A. Gasteiger, R.J. Behm, Electrochem. Commun. 1 (1999) 1.

[38] T. E. Lister, Y. Chu, W. Cullen, H. You, R. M. Yonco, J. F. Mithchell, Z. Nagy, J. Electroanal. Chem. 524-525 (2002) 201. 
[39] C. Bock, M.-A. Blakely, B. MacDougall, Electrochimca Acta 50, (2005) 2401. 


\section{Figure captions}

Figure 1. The XRD patterns of (a) cast $\mathrm{RuO}_{2} \mathrm{~ns}$ film, (b) $\mathrm{RuO}_{2} \mathrm{~ns}(0.5)-\mathrm{Pt} / \mathrm{C}$ (c) and $\mathrm{Pt} / \mathrm{C}$.

Figure 2. Cyclic voltammograms of $\mathrm{RuO}_{2} \mathrm{~ns} / \mathrm{C}$ at various temperatures in $0.5 \mathrm{M} \mathrm{H}_{2} \mathrm{SO}_{4}$ at $v=10$ $\mathrm{mV} \mathrm{s}^{-1}$.

Figure 3. $\mathrm{CO}_{\mathrm{ad}}$ stripping voltammograms for $\mathrm{RuO}_{2} \mathrm{~ns} / \mathrm{C}$ at various temperatures in $0.5 \mathrm{M} \mathrm{H}_{2} \mathrm{SO}_{4}$ at $\nu=10 \mathrm{mV} \mathrm{s}^{-1}$. Solid line: $1^{\text {st }}$ cycle after $\mathrm{CO}$ adsorption, broken line: $2^{\text {nd }}$ cycle. Current normalized with respect to the geometric surface.

Figure 4. Voltammograms of $\mathrm{RuO}_{2} \mathrm{~ns} / \mathrm{C}$ at (a) 25 , (b) 30 , (c) 40 , (d) 50 and (e) $60^{\circ} \mathrm{C}$ at $v=10 \mathrm{mV}$ $\mathrm{s}^{-1}$. Solid line: $0.5 \mathrm{M} \mathrm{H}_{2} \mathrm{SO}_{4}+1 \mathrm{M} \mathrm{CH}_{3} \mathrm{OH}$, broken line: $0.5 \mathrm{M} \mathrm{H}_{2} \mathrm{SO}_{4}$. Current normalized with respect to the geometric surface.

Figure 5. Cyclic voltammograms of (a) $\mathrm{RuO}_{2} \mathrm{~ns}(1.0)-\mathrm{Pt} / \mathrm{C}$, (b) $\mathrm{RuO}_{2} \mathrm{~ns}(0.5)-\mathrm{Pt} / \mathrm{C}$, (c) $\mathrm{RuO}_{2} \mathrm{~ns}(0.2)$ $\mathrm{Pt} / \mathrm{C}$, (d) and $\mathrm{Pt} / \mathrm{C}$ in $0.5 \mathrm{M} \mathrm{H}_{2} \mathrm{SO}_{4}\left(60^{\circ} \mathrm{C}\right)$ at $v=10 \mathrm{mV} \mathrm{s}{ }^{-1}$. Current normalized with respect to the Pt mass.

Figure 6. $\mathrm{CO}_{\mathrm{ad}}$ stripping voltammograms of (a) $\mathrm{RuO}_{2} \mathrm{~ns}(1.0)-\mathrm{Pt} / \mathrm{C}$, (b) $\mathrm{RuO}_{2} \mathrm{~ns}(0.5)-\mathrm{Pt} / \mathrm{C}$, (c) $\mathrm{RuO}_{2} \mathrm{~ns}(0.2)-\mathrm{Pt} / \mathrm{C}$, (d) $\mathrm{Pt} / \mathrm{C}$ and (e) $\mathrm{PtRu} / \mathrm{C}$ in $0.5 \mathrm{M} \mathrm{H}_{2} \mathrm{SO}_{4}\left(60^{\circ} \mathrm{C}\right)$ at $v=10 \mathrm{mV} \mathrm{s}^{-1}$. Solid line: $1^{\text {st }}$ cycle after $\mathrm{CO}$ adsorption, broken line: $2^{\text {nd }}$ cycle. Current normalized with respect to the Pt mass.

Figure 7. $\mathrm{CO}_{\mathrm{ad}}$ stripping voltammograms (difference spectra) for $\mathrm{RuO}_{2} \mathrm{~ns}(0.5)-\mathrm{Pt} / \mathrm{C}$ (solid line), $\mathrm{Pt} / \mathrm{C}$ (broken line) and $\mathrm{PtRu} / \mathrm{C}$ (dotted line) at various temperatures in $0.5 \mathrm{M} \mathrm{H}_{2} \mathrm{SO}_{4}$ at $v=10 \mathrm{mV} \mathrm{s}^{-}$

${ }^{1}$. Current normalized with respect to the Pt mass.

Figure 8. Chronoamperometry curves for (a) $\mathrm{RuO}_{2} \mathrm{~ns}(1.0)-\mathrm{Pt} / \mathrm{C}$, (b) $\mathrm{RuO}_{2} \mathrm{~ns}(0.5)-\mathrm{Pt} / \mathrm{C}$, (c) $\mathrm{RuO}_{2} \mathrm{~ns}(0.2)-\mathrm{Pt} / \mathrm{C}$, (d) $\mathrm{Pt} / \mathrm{C}$, and (e) and $\mathrm{PtRu} / \mathrm{C}$ in $0.5 \mathrm{M} \mathrm{H}_{2} \mathrm{SO}_{4}+1 \mathrm{M} \mathrm{CH}_{3} \mathrm{OH}\left(60^{\circ} \mathrm{C}\right)$ at $E=0.5$ $\mathrm{V}$ vs. RHE. Current normalized with respect to the Pt mass.

Figure 9. Voltammograms of $\mathrm{RuO}_{2} \mathrm{~ns}(0.5)-\mathrm{Pt} / \mathrm{C}$ (solid line), $\mathrm{Pt} / \mathrm{C}$ (dotted line) and $\mathrm{PtRu} / \mathrm{C}$ (broken line) at (a) 25 , (b) 30 , (c) 40 , (d) 50 and (e) $60^{\circ} \mathrm{C}$ in $0.5 \mathrm{M} \mathrm{H}_{2} \mathrm{SO}_{4}+1 \mathrm{M} \mathrm{CH}_{3} \mathrm{OH}$ at $v=10 \mathrm{mV} \mathrm{s}^{-1}$. Current normalized with respect to the Pt mass.

Figure 10. The mass activities of $\mathrm{RuO}_{2} \mathrm{~ns}(0.5)-\mathrm{Pt} / \mathrm{C}$ (circles), $\mathrm{Pt} / \mathrm{C}$ (triangles) and $\mathrm{PtRu} / \mathrm{C}$ (squares) at $30 \mathrm{~min}$ after the potential step to $0.5 \mathrm{~V}$ vs. RHE in $0.5 \mathrm{M} \mathrm{H}_{2} \mathrm{SO}_{4}+1 \mathrm{M} \mathrm{CH}_{3} \mathrm{OH}$ at various temperatures. Current normalized with respect to the Pt mass.

Figure 11. Cyclic voltammograms of (a, a') $\mathrm{RuO}_{2} \mathrm{~ns}(0.5)-\mathrm{Pt} / \mathrm{C},\left(\mathrm{b}, \mathrm{b}^{\prime}\right) \mathrm{Pt} / \mathrm{C}$ and (c, c') $\mathrm{PtRu} / \mathrm{C}$ before and after the stability test: (a) initial state of $\mathrm{RuO}_{2} \mathrm{~ns}(0.5)-\mathrm{Pt} / \mathrm{C}$, (a') after stability test of $\mathrm{RuO}_{2} \mathrm{~ns}(0.5)-\mathrm{Pt} / \mathrm{C}$, (b) initial state of $\mathrm{Pt} / \mathrm{C}$, (b') after stability test of $\mathrm{Pt} / \mathrm{C}$, (c) initial state of $\mathrm{PtRu} / \mathrm{C},\left(\mathrm{c}^{\prime}\right)$ after stability test of $\mathrm{PtRu} / \mathrm{C}$. Consecutive cycling test conditions: potential cycling between 0.05 to $1.2 \mathrm{~V}$ vs. RHE for 1,000 cycles at $50 \mathrm{mV} \mathrm{s}^{-1}$ in $0.5 \mathrm{M} \mathrm{H}_{2} \mathrm{SO}_{4}\left(60^{\circ} \mathrm{C}\right)$. Current normalized with respect to the Pt mass. 
Table I. Specific capacitance and electrochemically active Pt surface area $\left(S_{\mathrm{ECA}}\right)$ of $\mathrm{RuO}_{2} \mathrm{~ns}-\mathrm{Pt} / \mathrm{C}$ measured at $60^{\circ} \mathrm{C}$.

\begin{tabular}{ccc}
\hline \hline sample & \multicolumn{2}{c}{ Specific capacitance } \\
& $/ \mathrm{F}(\mathrm{g} \text {-composite })^{-1}$ & $S_{\mathrm{ECA}} / \mathrm{m}^{2}(\mathrm{~g}-\mathrm{Pt})^{-1}$ \\
\hline $\mathrm{RuO}_{2} \mathrm{~ns}(1.0)-\mathrm{Pt} / \mathrm{C}$ & 199 & 83 \\
$\mathrm{RuO}_{2} \mathrm{~ns}(0.5)-\mathrm{Pt} / \mathrm{C}$ & 166 & 64 \\
$\mathrm{RuO}_{2} \mathrm{~ns}(0.2)-\mathrm{Pt} / \mathrm{C}$ & 147 & 71 \\
$\mathrm{Pt} / \mathrm{C}$ & 97 & 52 \\
\hline
\end{tabular}


Table II. Methanol oxidation activity of $\mathrm{RuO}_{2} \mathrm{~ns}-\mathrm{Pt} / \mathrm{C}, \mathrm{Pt} / \mathrm{C}$ and $\mathrm{PtRu} / \mathrm{C}$.

\begin{tabular}{ccc}
\hline \hline sample & $\begin{array}{c}\text { Mass activity } \\
/ \mathrm{A}(\mathrm{g}-\mathrm{Pt})^{-1}\end{array}$ & $\begin{array}{c}\text { Specific activity } \\
/ \mathrm{A} \mathrm{m}^{-2}\end{array}$ \\
\hline $\mathrm{RuO}_{2} \mathrm{~ns}(1.0)-\mathrm{Pt} / \mathrm{C}$ & 42 & 0.50 \\
$\mathrm{RuO}_{2} \mathrm{~ns}(0.5)-\mathrm{Pt} / \mathrm{C}$ & 47 & 0.73 \\
$\mathrm{RuO}_{2} \mathrm{~ns}(0.2)-\mathrm{Pt} / \mathrm{C}$ & 5 & 0.11 \\
$\mathrm{Pt} / \mathrm{C}$ & 4 & 0.08 \\
$\mathrm{PtRu} / \mathrm{C}$ & 83 & 0.78 \\
\hline polarization potential :500 mV vs. RHE, electrolyte $: 0.5 \mathrm{M} \mathrm{H}_{2} \mathrm{SO}_{4}+1 \mathrm{M} \mathrm{CH}_{3} \mathrm{OH}\left(60^{\circ} \mathrm{C}\right)$
\end{tabular}

